\title{
Is there room for all of us? Renewable energy and Xerospermophilus mohavensis
}

\author{
Richard D. Inman ${ }^{1}$, Todd C. Esque ${ }^{1, *}$, Kenneth E. Nussear ${ }^{1}$, Philip Leitner ${ }^{2}$, \\ Marjorie D. Matocq ${ }^{3}$, Peter J. Weisberg ${ }^{3}$, Tomas E. Dilts ${ }^{3}$, Amy G. Vandergast ${ }^{4}$ \\ ${ }^{1}$ U.S. Geological Survey, Western Ecological Research Center, United States Geologic Survey, Las Vegas Field Station, \\ Henderson, Nevada 89074-8829, USA \\ ${ }^{2}$ California State University Stanislaus, Endangered Species Recovery Program, One University Circle, Turlock, \\ California 95382, USA \\ ${ }^{3}$ University of Nevada, Reno, Department of Natural Resources and Environmental Science, Program in Ecology, \\ Evolution and Conservation Biology, Reno, Nevada 89557, USA \\ ${ }^{4}$ U.S. Geological Survey, Western Ecological Research Center, San Diego Field Station, San Diego, California 92101, USA
}

\begin{abstract}
Mohave ground squirrels Xerospermophilus mohavensis Merriam are small grounddwelling rodents that have a highly restricted range in the northwest Mojave Desert, California, USA. Their small natural range is further reduced by habitat loss from agriculture, urban development, military training and recreational activities. Development of wind and solar resources for renewable energy has the potential to further reduce existing habitat. We used maximum entropy habitat models with observation data to describe current potential habitat in the context of future renewable energy development in the region. While $16 \%$ of historic habitat has been impacted by, or lost to, urbanization at present, an additional $10 \%$ may be affected by renewable energy development in the near future. Our models show that $X$. mohavensis habitat suitability is higher in areas slated for renewable energy development than in surrounding areas. We provide habitat maps that can be used to develop sampling designs, evaluate conservation corridors and inform development planning in the region.
\end{abstract}

KEY WORDS: Mohave ground squirrel . Renewable energy $\cdot$ Habitat suitability $\cdot$ Maximum entropy written consent of the publisher

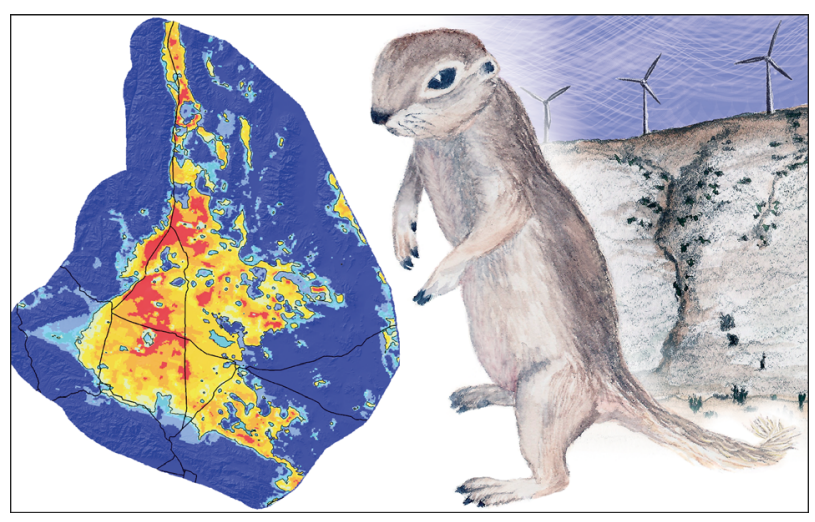

Xerospermophilus mohavensis, wind turbines, and predicted habitat suitability (in the Mojave Desert, California, USA) ranging from low (blue) to high (red).

Image: $M$. . A. Walden

\section{INTRODUCTION}

In recent decades the desert southwest region, including the Mojave Desert, has seen some of the highest population growth in the USA, resulting in large-scale landscape modification and loss of habitat (Leu et al. 2008). Habitat loss and modification due to urban development, utility infrastructure, transportation corridors, military training and recreational activities are occurring at an accelerating 
pace throughout the region (Lovich \& Bainbridge 1999, Webb et al. 2009). Now the southwestern deserts are recognized as having great potential for renewable energy development given the availability of public land and abundant wind, solar and geothermal resources (NREL 2012). In recent years, public policy initiatives at both federal and state levels (e.g. the American Recovery and Reinvestment Act of 2009, CA Executive Order S-14-08 and CA Senate Bill X1-2, among others) have mandated or encouraged the development of renewable energy.

One of the major benefits of increasing renewable energy generation includes reducing greenhouse gas emissions (thus mitigating global climate change), increasing national energy security and supporting economic growth. The potential for renewable energy in the desert means that public lands in this region are now in great demand for development. However, the prospect of large-scale energy development and its associated infrastructure has raised serious concerns regarding impacts on desert biological resources, including many sensitive or protected species such as the desert tortoise Gopherus agassizii (Fish and Wildlife Service 1990), the desert bighorn sheep Ovis canadensis nelsoni (Fish and Wildlife Service 1998) and Stephens' kangaroo rat Dipodomys stephensi (Fish and Wildlife Service 1988), among others.

The Mohave ground squirrel (MGS; Xerospermophilus mohavensis Merriam) could also be affected by the development of renewable energy resources. The species is endemic to the western Mojave Desert in California, USA, and occupies portions of Kern, Los Angeles, Inyo and San Bernardino counties (Best 1995). The geographic range is thought to be approximately $20000 \mathrm{~km}^{2}$ (Hall 1981, Zeiner et al. 19881990), one of the smallest distributions among North American ground squirrels (Hoyt 1972, P. Leitner pers. obs.). MGS occupy a harsh desert environment, and adult individuals are primarily active during a brief period from February to the end of July (Best 1995).

The restricted distribution of MGS, along with the extensive impacts of human development in the western Mojave Desert, has contributed to concern about conservation of this species (Leitner 2008). In particular, direct losses such as road and construction mortalities (Gustafson 1993) and the cumulative impacts (sensu Theobald et al. 1997) of landscapelevel disturbances (e.g. off-highway vehicles use, agriculture, military operations) could further reduce population numbers of MGS and connectivity of suitable habitat patches. In response to these concerns, MGS was listed as threatened under the California Endangered Species Act in 1984 (California Depart- ment of Fish and Game 2011). While habitat loss has been identified as the greatest peril for MGS (Fish and Wildlife Service 2011; see also Defenders of Wildlife \& G. Stewart at www.defenders.org/ newsroom/press_releases_folder/2005/09_13_2005_ protection_sought_for_mohave_desert_ground_squirrel .php), a comprehensive, range-wide assessment of habitat has not yet been published. Previous efforts to describe habitat have been qualitative, resulting in descriptions of habitat characteristics and multiple modifications to range maps (Zembal \& Gall 1980, Hall 1981, Zeiner et al. 1988-1990). While these range maps provide useful information on the known extent of a species, they do not delineate areas of habitat and non-habitat within their extant range, which can be problematic when used for assessing areas of high biodiversity for conservation purposes (Pineda \& Lobo 2012).

Conservation planning for many species has been facilitated by the use of species distribution models (SDMs) for tasks such as the design of conservation and monitoring programs, evaluating the efficacy or potential effects of management actions, and recovery planning (Graham et al. 2004, Elith \& Leathwick 2009a, Fish and Wildlife Service 2011). These SDMs, or habitat suitability models, are quantitative, spatially explicit models that relate species occurrence to environmental predictors thought to influence or define the suitability of habitat for the species (Franklin 2010, Peterson et al. 2011). These models can be ecologically complex or very simple, and can be modeled at many scales. Habitat models are frequently built with presence-only data (as absence data for most species are often unavailable), and provide a relative index of habitat suitability that can be predicted on a landscape scale.

Because SDMs have not yet been published for the MGS, conservation and planning decisions have been made entirely on previously published range maps. In 2011, a petition for federal listing of the species (www.defenders.org/newsroom/press_releases_folder/ 2005/09_13_2005_protection_sought_for_mohave_ desert_ground_squirrel.php) was deemed not warranted by the US Fish and Wildlife Service on the basis of 5 factors (Fish and Wildlife Service 2011). One of these factors included 'the present or threatened destruction, modification, or curtailment of its habitat or range', and in their ruling, the Fish and Wildlife Service provided estimates of minimal habitat loss due to land-use activities including urbanization, agriculture and renewable energy. These estimates were based on range maps that were the best available information for planning purposes in lieu of 
SDMs. However, a larger percentage of habitat has likely been lost in recent history than has been previously reported.

Conflicts between interests for large-scale renewable energy development in the western Mojave Desert and conservation of MGS habitat have delayed the establishment of energy facilities, and heightened the potential for costly litigation. Analyses on the extent to which habitat may or may not be affected by proposed utility-scale renewable energy development (USRED) are critically needed to reduce conflict between these competing interests, by guiding conservation planning and the effective siting of renewable energy projects and their supporting infrastructure. We provide the first comprehensive and integrated analysis of MGS habitat conservation in relation to previous development and planned USRED using SDMs. Our goal is to inform decision-makers representing public interests such as the Desert Renewable Energy Conservation Plan (DRECP; www.drecp.org) charged with balancing the need for landscape planning and conservation needs, while ensuring the availability of renewable energy resources.

\section{MATERIALS AND METHODS}

\section{Study area}

Our study area covers $53621 \mathrm{~km}^{2}$ of the Mojave Desert in California, including portions of Inyo, San Bernardino, Kern and Los Angeles counties, and encompasses the entire known historical range of the MGS (Zeiner et al. 1988-1990). The region is characterized by desert mountain ranges and plateaus separated by lower elevation areas with geomorphic features such as washes, outwash plains, dry lakebeds and basins. Although our study area includes extremes in elevation, $99 \%$ of the entire study area is below $2500 \mathrm{~m}$. Regional precipitation ranges from 100 to $350 \mathrm{~mm}$ per year, with more rainfall occurring in the winter than in the summer (Hereford et al. 2004, Blainey et al. 2007) and at higher elevations. Temperatures range from below $0^{\circ} \mathrm{C}$ in the winter months to over $54^{\circ} \mathrm{C}$ in the summer, with considerable daily and geographic variation (Turner 1994).

\section{Species occurrence data}

We compiled locality records for the MGS from the California Natural Diversity Data Base (CNDDB), the Mojave Desert Ecosystem Program, as well as recent trapping and survey work (P. Leitner \& D. Delaney unpubl. data). Due to the low density of sampling and biased geographic distribution of observations, we included records dating back to 1975 to increase sample size. Records with known spatial uncertainty greater than $1 \mathrm{~km}$ (33 records) were excluded to keep the spatial precision of MGS observations similar to that of the environmental data layers, and the desired resolution of the habitat model (i.e. $1 \mathrm{~km}^{2}$ ). We limited observations to 1 per $1 \mathrm{~km}^{2}$ grid cell, and incorporated a bias file to reduce the influence of biased geographic sampling (Phillips \& Dudik 2008), which used a $4 \mathrm{~km}$ search radius from each observation record. After aggregating to our $1 \mathrm{~km}^{2}$ grid size, there were a total of 440 observations for modeling.

\section{Environmental data}

The relationship between habitat suitability and covariate layers in a robust habitat model should ideally be explained by known ecological relationships between the organism of interest and its environment (Guisan \& Zimmermann 2000, Elith \& Leathwick 2009b). We derived 8 environmental covariates across our study area capturing known relationships between MGS and their environment (Table 1). These layers broadly represented climate (e.g. air temperature, precipitation and climatic water deficit), land surface characteristics (e.g. topographic position and surface roughness) and the physical properties of the land surface (e.g. surface texture and albedo). The habitats that MGS occupy are generally flat, sandy or gravelly alluvial substrates with widely spaced shrubs (Burt 1936, Best 1995, Leitner 2008). Occupied vegetation types can include saltbush scrub, alkali desert scrub, creosote bush scrub and yucca woodlands (Gustafson 1993, Best 1995). MGS are not, however, generally found on playas, rocky outcrops or other rocky surfaces such as desert pavement or boulder fields (Zembal \& Gall 1980, Gustafson 1993). Because this work is also being used in parallel analyses of the potential effects of climate change on MGS habitat suitability, we only included environmental covariates that could be projected to future dates under different climate change/global emissions scenarios. Therefore, we did not include any measures of vegetation community or condition. While habitat suitability models derived without layers of key vegetation components of habitat may not represent the complete fundamental niche of a species, they can have acceptable predictive performance; for example, some of our initial models sug- 
Table 1. Abbreviations, study area means, standard deviations and descriptions of environmental variables used in the present study

\begin{tabular}{|c|c|c|c|c|}
\hline Variable & Abbreviation & Mean & $\mathrm{SD}$ & Description \\
\hline $\begin{array}{l}\text { Precipitation } \\
\text { (cumulative winter) }\end{array}$ & PRCP & 195.3 & 161.0 & $\begin{array}{l}\text { Cumulative winter (Oct-Mar) precipitation (mm), } \\
\text { average of } 30 \mathrm{yr}(1980-2010) .\end{array}$ \\
\hline Surface texture & $\mathrm{ST}$ & 1103.5 & 205.0 & $\begin{array}{l}\text { Average difference in daytime and nighttime radio- } \\
\text { metric surface temperatures }\left({ }^{\circ} \mathrm{C} \text { ) (Moderate Resolution }\right. \\
\text { Imaging Spectroradiometer MOD11A1 Land Surface } \\
\text { Temperature } 8 \text {-d Global } 1 \mathrm{~km} \text { data product) for the six } \\
\text { 8-d periods from } 12 \mathrm{Jul} \text { to } 29 \text { Aug for each year from } \\
2000 \text { to } 2010 \text {. Higher values are indicative of sandy, } \\
\text { smaller sized particles; smaller values represent more } \\
\text { rocky surfaces. }\end{array}$ \\
\hline Surface albedo & ALB & 265.7 & 63.7 & $\begin{array}{l}\text { Average of summer (Jun-Aug) diffuse bihemispherical } \\
\text { albedo, derived from the MODIS MCD43B3 16-d L3 } \\
\text { Global } 1 \mathrm{~km} \text { Albedo data product for } 2010 .\end{array}$ \\
\hline $\begin{array}{l}\text { Climatic water deficit } \\
\text { (winter mean) }\end{array}$ & CWD & 36.6 & 17.9 & $\begin{array}{l}\text { Average winter climatic water deficit (mm), average of } \\
30 \text { yr (1980-2010) for the months of Oct-Mar. High } \\
\text { values represent greater evaporative demand on an } \\
\text { area not met by available soil water. }\end{array}$ \\
\hline Topographic position & TPX & 8.7 & 2.1 & $\begin{array}{l}\text { Relative position of a given cell with respect to the } \\
\text { potential for surface drainage. Calculated from the } \\
\text { USGS National Elevation Dataset (NED) (Moore et al. } \\
\text { 1991). Higher values are indicative of dry lakebeds, } \\
\text { valley bottoms and surface flow pinch points such as } \\
\text { apexes of alluvial fans; lower values represent } \\
\text { ridgelines and mountaintops. }\end{array}$ \\
\hline $\begin{array}{l}\text { Probability of } 3 \mathrm{yr} \\
\text { drought }\end{array}$ & PD3 & 0.05 & 0.10 & $\begin{array}{l}\text { Proportion of the past } 30 \mathrm{yr}(1980-2010) \text { with } 3 \\
\text { consecutive years with }<80 \mathrm{~mm} \text { of cumulative winter } \\
\text { precipitation. }\end{array}$ \\
\hline $\begin{array}{l}\text { Maximum summer air } \\
\text { temperature }\end{array}$ & $T \max$ & 30.78 & 5.28 & $\begin{array}{l}\text { Maximum of the monthly summer average (Apr-Oct) } \\
\text { temperatures from past } 30 \mathrm{yr} \text {. }\end{array}$ \\
\hline Surface roughness & SR & 1.03 & 0.05 & $\begin{array}{l}\text { Surface roughness index is calculated from the USGS } \\
\text { Digital Elevation Model (DEM) (Hobson 1972). Higher } \\
\text { values indicate a greater amount of surface terrain } \\
\text { relief in a given area. }\end{array}$ \\
\hline
\end{tabular}

gested only a 0.017 difference in the area under the receiver operator curve statistic (AUC) (Fielding \& Bell 1997) between the best-performing models that included vegetation layers and those without.

Climate covariates were obtained for our study area at a spatial scale of $270 \mathrm{~m}$ (Flint \& Flint 2012), and included the $30 \mathrm{yr}$ mean for the winter months (October-March) of climatic water deficit, and the $30 \mathrm{yr}$ mean of cumulative winter precipitation. Climatic water deficit was defined as potential evapotranspiration minus actual evapotranspiration, where actual evapotranspiration is the amount of water that evaporates from the surface and is transpired by plants if the total amount of water is not limited. It is a measure of the evaporative demand on an area that was not met by available soil water, and is related to the amount of drought stress experienced by plants (Lenihan \& Neilson 1993, Stephenson 1998). While often used to model the distribution of plant communities (see Prentice et al. 1992, Huntley et al. 1995), climatic water deficit is not often used in predictive models of vertebrates, likely due to the lack of widely available soil data required for its calculation. We use it here as a surrogate representing a potential limiting factor for vegetation. Potential evapotranspiration was defined as the total amount of water that can evaporate from the ground surface or be transpired by plants, and was calculated using a modification of the Priestley-Taylor equation (Priestley \& Taylor 1972) as described in Flint et al. (2004). 
Winter rainfall is important for the spring production of annuals (Beatley 1976, Turner \& Randall 1989), and because MGS are generally only active from February to the end of July (Bartholomew \& Hudson 1961, Hoyt 1972, Gustafson 1993, Harris \& Leitner 2004), they require extensive foraging to sustain metabolic function throughout the year (Bartholomew \& Hudson 1961). Areas with high spring production of annuals are therefore typically considered as habitat for this species. The probability of drought was estimated as the proportion of the past $30 \mathrm{yr}$ (1980-2010) during which 3 consecutive years had less than $80 \mathrm{~mm}$ of cumulative winter precipitation for a given $1 \mathrm{~km}^{2}$ grid cell. We chose $80 \mathrm{~mm}$ to define drought conditions based on observations of MGS behavior and habitat condition (P. Leitner. pers. comm.). A measure of air temperature was included as the 30 yr mean for summer maximum temperature.

Layers related to land surface characteristics included surface roughness (Hobson 1972) and topographic position (described by others as 'terrain wetness', Moore et al. 1991). Topographic position was used to represent the relative position of a given area with respect to the potential for surface drainage, and was calculated from the area of terrain that can drain into a given $1 \mathrm{~km}^{2}$ grid cell. Higher values are indicative of closed basins, valley bottoms and surface flow pinch points such as apexes of alluvial fans, while lower values represent ridgelines and mountaintops. We did not include elevation as an environmental covariate, due to its high correlation with several of the climate variables and potential to complicate future climate scenario models.

Layers representing the physical properties of the surface substrate included an index of the particle size of the surface substrate (surface texture), which was derived from the Moderate Resolution Imaging Spectroradiometer (MODIS) MOD11A1 Land Surface Temperature 8-d Global $1 \mathrm{~km}$ data products acquired from the Terra (EOS AM) satellite. This index was the average difference in daytime and nighttime radiometric surface temperatures for the six 8-d periods from 12 July to 29 August for each year from 2000 to 2010 . The difference between the day and night surface radiometric temperatures is a function of the daily thermal inertia of the surface substrate, which is a physical property of the substrate material and texture (Pratt \& Ellyett 1979, Kahle 1987, Wang et al. 2004). Areas with dense rocky substrates have less daily fluctuation in surface radiometric temperatures than do areas with loose or sandy substrates (Kahle 1987). We used summer, rather than winter, temperatures due to the greater differences observed between day and night temperatures during this period (S. Nowiki unpubl. data). Higher values are indicative of sandy, smaller sized particles, while smaller values represent more rocky surfaces. Prior to calculating surface texture, surface temperature data were de-trended for elevation using a non-linear weighted regression.

We also included the albedo of the surface substrate (surface albedo) from the MODIS MCD43B3 16-Day L3 Global $1 \mathrm{~km}$ Albedo data product for the summer months as a measure of directional-hemispherical reflectivity of the surface material to represent dominant surface material types. Surface albedo is a primary determinant of the thermal properties of a surface material (Dickinson 1995), and is determined by the material type of the surface layer (Oke 1987). Prior to use in habitat models, all of the layers were re-sampled to the same $1 \mathrm{~km}^{2}$ grid.

\section{Data analyses}

We used MaxEnt (version 3.3.3e, Phillips et al. 2006) to develop a suite of candidate habitat models with up to 5 of the aforementioned environmental covariates. Each model was derived using 100 bootstrapped replicates with a random sample of $80 \%$ of the occurrences used for model training. We excluded variables if their Pearson's correlation coefficient with other inputs was greater than 0.7 . The resulting habitat models were first evaluated with an information theoretic approach using a modified corrected Akaike's information criterion (AICc) score that was bias corrected for small sample sizes (Burnham \& Anderson 2002). This metric was derived from the estimated log likelihood at all of presence locations (Phillips \& Dudik 2008, Elith et al. 2011), where the number of parameters in the fitted model was defined by the sum of all non-zero lambdas for a given model (Warren \& Seifert 2011). Models with parsimony were also evaluated for accuracy, goodness-of-fit and plausibility with several additional methods, including AUC and the Boyce index (BI) (Boyce et al. 2002), testing gain (GAIN) (Elith et al. 2011) as well as marginal and solitary response curves (Phillips \& Dudik 2008). The AUC statistic was calculated from an internally withheld set of $20 \%$ of the MGS presence locations for each bootstrapped replicate, while the BI was estimated with all of the MGS observations. Prior to estimating the BI, each habitat model was rescaled to ensure that all models ranged from [0 - 1] by subtracting the minimum value and dividing by the difference of the minimum and maximum values. 
Models containing any covariates with less than $10 \%$ contribution were removed from our suite of candidate models, favoring robust covariates over those with little contribution. We checked the prediction surfaces for each of the models to ensure that the predictions were not unrealistic, especially in areas where few data were available, but where we had some personal knowledge (P. Leitner) of habitat. We selected the model that appeared closest to reality among our suite of candidate models to represent MGS habitat suitability. This model and its uncertainty were derived as the mean and standard deviation of the habitat suitability scores across all 100 bootstrapped replicates. To gain insight into the key predictors defining habitat for MGS, we also assessed which of the environmental covariates was the most limiting with respect to habitat suitability throughout our study area. The limiting variable was taken as the environmental covariate that provided the greatest increase in habitat suitability in a given pixel if the value for that variable was adjusted to the mean of the entire study area (Elith et al. 2010).

\section{Anthropogenic impacts}

We examined current impacts on habitat due to human development using 3 impact scenarios (high, medium and low) representing 3 possible levels of degradation of MGS habitat by anthropogenic influences of urbanization, extensive road networks, and cleared or altered vegetation. For each of these anthropogenic influences, we derived separate scale factors for the 3 impact scenarios with which we reduced habitat suitability in affected areas. Few data exist to suggest quantitative relationships between anthropogenic influences and MGS habitat degradation, and therefore our impact scenarios represent a range of uncertainty in the effects of habitat degrada- tion rather than known and tested relationships. We derived our scale factors for each of the impact scenarios from expert opinion based on field observations. Our high impact scenario uses scale factors representing the most extreme, yet plausible, degradation to MGS habitat, while our low impact scenario represents an underestimate of degradation to MGS habitat. The medium impact scenario was defined as the middle point between the high and low impact scenarios. Combined, these 3 scenarios present a range of reasonable estimates of habitat suitability from least to most conservative, and can provide a bounded assessment of the status of habitat for land management purposes in light of anthropogenic influences.

Urban areas were derived from the 2006 National Land Change Database (NLCD) Percent Developed Imperviousness layer, downloaded from the MultiResolution Land Characteristics Consortium (Fry et al. 2011). Grid cells with more than $20 \%$ of their surface area covered by at least $20 \%$ imperviousness were categorized as urban. Our scale factors in urban areas for the 3 impact scenarios were as follows: 1.0 for high, 0.75 for medium and 0.30 for low (Table 2). In these areas, we subtracted the product of the habitat suitability score and the scale factor from the habitat suitability score for each cell. For example, in the high impact scenario, a cell with a habitat suitability score of 0.65 that was located in an area classified as urban was modified by subtracting the product of the habitat suitability score (0.65) and the scale factor for urban areas (1.0) from the habitat suitability score (0.65), yielding a new habitat suitability score of 0 . In the high impact scenario, we assume that urban areas present a complete loss of habitat, such that none of the essential resources (especially food and cover) are available. In contrast, our low impact scenario represents the assumption that only a slight degradation of habitat has occurred in urban areas.

Table 2. Scale factors and suitable habitat for impact scenarios. (-) scale factors were not used for a particular scenario; USRED: utility-scale renewable energy development

\begin{tabular}{|c|c|c|c|c|c|c|c|c|c|}
\hline \multirow[t]{3}{*}{ Energy } & \multirow{3}{*}{$\begin{array}{l}\text { Impact } \\
\text { scenario }\end{array}$} & \multicolumn{6}{|c|}{ Scale factor $\longrightarrow$} & \multirow{3}{*}{$\begin{array}{c}\text { Suitable } \\
\text { habitat }\left(\mathrm{km}^{2}\right)\end{array}$} & \multirow{3}{*}{$\begin{array}{c}\% \text { Loss of } \\
\text { historic } \\
\text { habitat }\end{array}$} \\
\hline & & \multicolumn{3}{|c|}{ Anthropogenic influences } & \multicolumn{3}{|c|}{ Renewable energy influences } & & \\
\hline & & Urban & Roads & $\begin{array}{c}\text { Agriculture/ } \\
\text { cleared vegetation }\end{array}$ & $\begin{array}{l}\text { Transmission } \\
\text { corridors }\end{array}$ & Wind & Solar & & \\
\hline None & Historic & - & - & - & - & - & - & 19023 & - \\
\hline \multirow[t]{3}{*}{ None } & Low & 0.300 & 0.100 & 0.500 & - & - & - & 17139 & 9.9 \\
\hline & Medium & 0.750 & 0.250 & 0.750 & - & - & - & 16525 & 13.1 \\
\hline & High & 1.000 & 0.400 & 1.000 & - & - & - & 15927 & 16.3 \\
\hline \multirow[t]{3}{*}{ USRED } & Low & 0.300 & 0.100 & 0.500 & 0.100 & 0.100 & 0.750 & 17058 & 10.3 \\
\hline & Medium & 0.750 & 0.250 & 0.750 & 0.250 & 0.250 & 0.875 & 16142 & 15.1 \\
\hline & High & 1.000 & 0.400 & 1.000 & 0.500 & 0.500 & 1.000 & 14369 & 24.5 \\
\hline
\end{tabular}


We identified major roads from US Census Bureau TIGER line files and assigned scale factors for each of the impact scenarios: 0.4 for high, 0.25 for medium and 0.10 for low. While there is evidence to suggest direct mortality from vehicular traffic and the construction of new roads (P. Leitner pers. comm.), recent work has shown that many small mammals exhibit neutral or slightly positive responses in abundance to the presence of roads and vehicular traffic (Fahrig \& Rytwinski 2009). In the absence of data for MGS, we used scale factors that reflected the potential for only minimal impact on MGS habitat.

As with urban areas, we assumed that places where land-use activities have visibly altered or removed vegetation, such as agricultural or military activities, present significant degradation to MGS habitat. In addition to the direct loss of habitat, these activities may introduce insecticides, herbicides and rodenticides to habitat (Hoyt 1972). These areas were digitized from recent remote sensing imagery where at least $90 \%$ of each grid cell showed evidence of altered or cleared vegetation. Here, scale factors of 0.1 (high), 0.75 (medium) and 0.5 (low) were applied. We reduced the habitat suitability scores in these areas because of the importance of shrubs to MGS habitat (Best 1995).

We assessed the effects of these 3 types of anthropogenic impact on MGS habitat by categorizing habitat suitability into a binary representation of suitable and unsuitable habitat for each of the 3 impact scenarios using the 5th percentile of habitat suitability scores (0.438 was used as the threshold) for all of the cells with MGS occurrences (Liu et al. 2005). This resulted in the total area of suitable MGS habitat for each of the 3 scenarios, which we compared against the amount of suitable habitat predicted in absence of urban development, roads or cleared vegetation to provide a historical perspective of how much habitat might have existed prior to urbanization in the region.

\section{Renewable energy}

We evaluated the extent and degree to which suitable MGS habitat will be affected by proposed utilityscale renewable energy development (USRED) by compiling a spatial representation of current and proposed renewable energy development on Bureau of Land Management (BLM) lands in California from the Solar Energy Development Programmatic Environmental Impact Statement (BLM 2012). We also included areas designated as transmission corridors under the California Desert Conservation Area Plan of 1980 (BLM 1980), and the West-wide Designation of Energy Corridors (BLM 2009). Additional renewable energy projects (such as wind and geothermal sites) and their associated spatial footprints were identified and provided by the Renewable Energy Project Manager for the California Desert BLM District Office (G. Miller unpubl. data). As with our urban impact scenarios, we developed 3 scenarios of impact by USRED on MGS habitat. Again, few data are available to quantify the relationship between USRED and degradation of MGS habitat, and we therefore used expert opinion to derive our scale factors. Recent work on the California ground squirrel Otospermophilus beecheyi has suggested that wind energy facilities can cause an increase in alert vocalizations and anti-predator vigilance behavior in individuals (Rabin et al. 2006), though estimates of the effects on their habitat or a population are lacking. Similarly, transmission corridors are thought to have slight negative effects on many ground-dwelling species through the introduction of predators and exotic species (Stiles \& Jones 1998, Gelbard \& Belnap 2003), and alteration of vegetation communities (Loft \& Menke 1984, Clarke et al. 2006, King et al. 2009). Due to the similarities in perceived degradation of MGS habitat by wind energy developments and transmission corridors, we derived scale factors for both of $0.5,0.3$ and 0.1 for the high, medium and low renewable energy impact scenarios, respectively. We assumed that solar energy developments have a greater impact on MGS habitat due to their extensive alteration of vegetation and soil characteristics (BLM 2012), and therefore assigned scale factors of 1.0, 0.875 and 0.75 for each of the high, medium and low renewable energy impact scenarios, respectively. We acknowledge that few data are available to quantify the impacts of USRED on MGS habitat, and therefore these scale factors are educated approximations, derived from observations of current USRED in locations outside the previously published range of the MGS (Zeiner et al. 1988-1990).

We evaluated the extent and the degree to which MGS habitat could be affected in the context of USRED by calculating the total amount of suitable habitat in each of the 3 USRED and 3 urban development scenarios of impact. For each of these 6 scenarios, we calculated the total area of suitable habitat in our study area that resulted from applying the scale factors. Separately, we compared the mean of habitat suitability scores in USRED (without the USRED impact scenarios) with the remainder of the study area for each of the urban development scenarios of impact to identify whether areas with proposed 
USRED have greater habitat suitability for MGS than the rest of the study area. We also report the difference in area between solar and wind USRED in terms of suitable habitat.

\section{RESULTS}

\section{Habitat models}

From the 86 models initially evaluated we selected a model with 4 environmental covariates to best represent habitat, which had the lowest AICc score. This model also had the highest AUC and GAIN, and was among the higher performing models with respect to $\mathrm{BI}$, although none of these performance measures indicated as strong a difference as the AICc criterion (Table 3). The environmental covariates in the best model included: surface texture, surface albedo, mean winter climatic water deficit and precipitation, with percent contributions of 46.6, 25.4, 16.3 and $11.6 \%$, respectively. Each of these environmental covariates describes a component of the broad habitat characteristics that we hypothesized to be important for MGS. These characteristics spanned climatic, topographic and terrain features, and are related to the behavioral and physiological ecology of the MGS.

Marginal response curves for the environmental covariates in the selected model had patterns that were consistent with our hypotheses about their relationships to MGS habitat. Of the 4 environmental covariates, surface texture had the highest percent contribution at $46.6 \%$. MGS habitat suitability peaked in areas where the difference between day and night surface radiant temperatures was between 25 and $30^{\circ} \mathrm{C}$, which was consistent with surface textures found in moderately coarse sandy soils. Habitat suitability decreased sharply when radiant temperature differences were below $20^{\circ} \mathrm{C}$ (Fig. 1), corresponding

Table 3. Performance measures and variable contributions of candidate models. Performance measures included: number of parameters $\left(\mathrm{N}_{\mathrm{par}}\right)$, change in corrected Akaike's information criterion $(\triangle \mathrm{AICc})$, area under the receiver operating characteristic curve (AUC), Boyce Index (BI) and testing gain (GAIN). Variable abbreviations are defined as follows: mean winter climatic water deficit (CWD), mean cumulative winter precipitation (PRCP), summer maximum temperature (Tmax), probability of 3 yr drought (PD3), surface texture (ST), surface albedo (ALB), surface roughness (SR) and topographic position (TPX). Blank cells indicate models where that particular variable was not included

\begin{tabular}{|c|c|c|c|c|c|c|c|c|c|c|c|c|c|}
\hline \multirow[t]{2}{*}{ Model } & \multirow{2}{*}{$\mathrm{N}_{\text {par }}$} & \multicolumn{4}{|c|}{ — Performance metric -} & \multirow[b]{2}{*}{$\mathrm{ST}$} & \multirow[b]{2}{*}{ ALB } & \multirow[b]{2}{*}{ TPX } & \multicolumn{3}{|c|}{ - \% Contribution } & \multirow[b]{2}{*}{ PRCP } & \multirow[b]{2}{*}{ PD3 } \\
\hline & & $\triangle \mathrm{AICc}$ & AUC & BI & GAIN & & & & SR & $T \max$ & CWD & & \\
\hline $\mathrm{ST}+\mathrm{CWD}+\mathrm{ALB}+\mathrm{PRCP}$ & 4 & 0 & 0.888 & 0.950 & 1.133 & 46.6 & 25.4 & & & & 16.3 & 11.7 & \\
\hline $\mathrm{ST}+\mathrm{CWD}+\mathrm{ALB}$ & 3 & 77.755 & 0.864 & 0.949 & 1.000 & 51.1 & 29.0 & & & & 19.9 & & \\
\hline $\mathrm{CWD}+\mathrm{ALB}+\mathrm{PRCP}$ & 3 & 94.367 & 0.863 & 0.968 & 0.977 & & 55.9 & & & & 26.1 & 18.0 & \\
\hline $\mathrm{ST}+\mathrm{ALB}+\mathrm{PRCP}$ & 3 & 107.728 & 0.867 & 0.986 & 1.007 & 51.7 & 30.6 & & & & & 17.8 & \\
\hline $\mathrm{ST}+\mathrm{CWD}+\mathrm{PRCP}$ & 3 & 114.677 & 0.867 & 0.878 & 0.987 & 65.8 & & & & & 20.2 & 14.0 & \\
\hline $\mathrm{ST}+T \max +\mathrm{CWD}$ & 3 & 124.178 & 0.863 & 0.959 & 0.959 & 66.4 & & & & 14.4 & 19.2 & & \\
\hline$T \max +\mathrm{CWD}+\mathrm{ALB}$ & 3 & 126.674 & 0.863 & 0.962 & 0.978 & & 59.6 & & & 13.6 & 26.8 & & \\
\hline CWD+ALB & 2 & 138.860 & 0.858 & 0.976 & 0.949 & & 63.8 & & & & 36.2 & & \\
\hline $\mathrm{ST}+\mathrm{CWD}$ & 2 & 158.554 & 0.858 & 0.878 & 0.939 & 72.2 & & & & & 27.8 & & \\
\hline $\mathrm{ST}+T \max +\mathrm{ALB}$ & 3 & 181.443 & 0.854 & 0.946 & 0.923 & 56.8 & 31.4 & & & 11.8 & & & \\
\hline Tmax+ALB+PRCP & 3 & 191.524 & 0.856 & 0.939 & 0.915 & & 61.8 & & & 12.1 & & 26.1 & \\
\hline $\mathrm{ST}+\mathrm{CWD}+\mathrm{PRCP}+\mathrm{SR}$ & 4 & 195.071 & 0.856 & 0.995 & 0.898 & 54.9 & & & 12.0 & & 21.8 & 11.2 & \\
\hline $\mathrm{ST}+\mathrm{CWD}+\mathrm{TPX}+\mathrm{ALB}$ & 4 & 202.918 & 0.854 & 0.986 & 0.906 & 43.4 & 21.9 & 10.4 & & & 24.3 & & \\
\hline $\mathrm{ALB}+\mathrm{PRCP}$ & 2 & 208.639 & 0.853 & 0.972 & 0.902 & & 66.6 & & & & & 33.4 & \\
\hline $\mathrm{ST}+\mathrm{ALB}$ & 2 & 212.186 & 0.847 & 0.961 & 0.884 & 65.0 & 35.0 & & & & & & \\
\hline $\mathrm{ST}+\mathrm{PRCP}$ & 2 & 213.360 & 0.847 & 0.925 & 0.875 & 74.0 & & & & & & 26.0 & \\
\hline $\mathrm{CWD}+\mathrm{ALB}+\mathrm{PRCP}+\mathrm{SR}$ & 4 & 218.721 & 0.850 & 0.967 & 0.885 & & 45.3 & & 13.0 & & 29.6 & 12.2 & \\
\hline $\mathrm{CWD}+\mathrm{ALB}+\mathrm{SR}$ & 3 & 228.539 & 0.844 & 0.970 & 0.854 & & 43.7 & & 19.4 & & 36.8 & & \\
\hline Tmax+ALB+PD3 & 3 & 241.093 & 0.841 & 0.958 & 0.853 & & 67.0 & & & 19.0 & & & 14.0 \\
\hline CWD+TPX+ALB & 3 & 242.998 & 0.840 & 0.995 & 0.835 & & 41.6 & 21.3 & & & 37.1 & & \\
\hline $\mathrm{ST}+\mathrm{CWD}+\mathrm{SR}$ & 3 & 247.529 & 0.847 & 0.964 & 0.845 & 56.7 & & & 12.6 & & 30.7 & & \\
\hline $\mathrm{ST}+\mathrm{CWD}+\mathrm{TPX}$ & 3 & 252.644 & 0.845 & 0.961 & 0.843 & 55.1 & & 16.0 & & & 28.9 & & \\
\hline $\mathrm{ST}+T \max$ & 2 & 258.912 & 0.833 & 0.928 & 0.804 & 77.6 & & & & 22.4 & & & \\
\hline$T \max +\mathrm{CWD}+\mathrm{PRCP}+\mathrm{SR}$ & 4 & 259.315 & 0.848 & 0.970 & 0.842 & & & & 40.3 & 13.9 & 35.3 & 10.5 & \\
\hline Tmax+CWD+PRCP & 3 & 259.593 & 0.850 & 0.951 & 0.858 & & & & & 27.2 & 41.2 & 31.7 & \\
\hline $\mathrm{CWD}+\mathrm{TPX}+\mathrm{PRCP}+\mathrm{SR}$ & 4 & 262.753 & 0.842 & 0.965 & 0.804 & & & 33.7 & 14.9 & & 37.1 & 14.3 & \\
\hline CWD+TPX+PRCP & 3 & 274.594 & 0.840 & 0.946 & 0.807 & & & 46.2 & & & 39.8 & 14.1 & \\
\hline
\end{tabular}


Table 3. (continued)

\begin{tabular}{|c|c|c|c|c|c|c|c|c|c|c|c|c|c|}
\hline \multirow[t]{2}{*}{ Model } & \multirow[t]{2}{*}{$\mathrm{N}_{\mathrm{par}}$} & \multicolumn{4}{|c|}{$\ldots$ Performance metric -} & \multirow[b]{2}{*}{ ST } & \multirow[b]{2}{*}{ ALB } & \multirow[b]{2}{*}{ TPX } & \multicolumn{3}{|c|}{ - \% Contribution } & \multirow[b]{2}{*}{ PRCP } & \multirow[b]{2}{*}{ PD3 } \\
\hline & & $\triangle \mathrm{AICc}$ & AUC & BI & GAIN & & & & SR & $T \max$ & CWD & & \\
\hline Tmax+ALB & 2 & 281.308 & 0.837 & 0.936 & 0.823 & & 70.2 & & & 29.8 & & & \\
\hline $\mathrm{ALB}+\mathrm{PD} 3$ & 2 & 291.562 & 0.830 & 0.986 & 0.777 & & 82.0 & & & & & & 18.0 \\
\hline $\mathrm{Tmax}+\mathrm{CWD}+\mathrm{TPX}+\mathrm{SR}$ & 4 & 294.414 & 0.835 & 0.978 & 0.792 & & & 32.7 & 15.9 & 13.4 & 38.0 & & \\
\hline $\mathrm{ALB}+\mathrm{PRCP}+\mathrm{SR}$ & 3 & 294.605 & 0.838 & 0.990 & 0.799 & & 48.9 & & 19.3 & & & 31.8 & \\
\hline $\mathrm{CWD}+\mathrm{PRCP}+\mathrm{SR}$ & 3 & 296.035 & 0.839 & 0.966 & 0.806 & & & & 44.7 & & 40.8 & 14.5 & \\
\hline $\mathrm{ST}+\mathrm{TPX}+\mathrm{PRCP}$ & 3 & 297.588 & 0.836 & 0.974 & 0.795 & 61.0 & & 18.1 & & & & 20.9 & \\
\hline CWD+TPX+SR & 3 & 297.593 & 0.837 & 0.993 & 0.803 & & & 35.8 & 16.2 & & 48.0 & & \\
\hline Tmax+CWD+TPX & 3 & 307.932 & 0.839 & 0.963 & 0.804 & & & 45.2 & & 14.8 & 40.0 & & \\
\hline Tmax+CWD+SR & 3 & 309.179 & 0.832 & 0.950 & 0.757 & & & & 43.2 & 18.3 & 38.5 & & \\
\hline Tmax+ALB+PRCP+SR & 4 & 314.627 & 0.833 & 0.986 & 0.774 & & 51.1 & & 18.0 & 10.8 & & 20.2 & \\
\hline TPX+ALB+PRCP & 3 & 322.969 & 0.832 & 0.998 & 0.777 & & 44.8 & 26.2 & & & & 28.9 & \\
\hline CWD+TPX & 2 & 324.230 & 0.831 & 0.978 & 0.768 & & & 49.8 & & & 50.2 & & \\
\hline $\mathrm{ST}+\mathrm{PRCP}+\mathrm{SR}$ & 3 & 331.655 & 0.833 & 0.971 & 0.767 & 69.3 & & & 10.5 & & & 20.2 & \\
\hline$T \max +\mathrm{CWD}$ & 2 & 331.813 & 0.834 & 0.981 & 0.774 & & & & & 52.5 & 47.5 & & \\
\hline $\mathrm{Tmax}+\mathrm{ALB}+\mathrm{PD} 3+\mathrm{SR}$ & 4 & 332.233 & 0.831 & 0.987 & 0.782 & & 49.0 & & 20.1 & 11.2 & & & 19.7 \\
\hline $\mathrm{ST}+\mathrm{Tmax}+\mathrm{TPX}+\mathrm{PD} 3$ & 4 & 340.348 & 0.824 & 0.976 & 0.739 & 60.7 & & 16.8 & & 11.4 & & & 11.1 \\
\hline $\mathrm{ST}+\mathrm{Tmax}+\mathrm{PD} 3+\mathrm{SR}$ & 4 & 341.030 & 0.828 & 0.984 & 0.761 & 65.4 & & & 12.2 & 11.8 & & & 10.7 \\
\hline Tmax+TPX+PRCP+SR & 4 & 351.642 & 0.836 & 0.975 & 0.766 & & & 37.6 & 17.4 & 16.0 & & 29.1 & \\
\hline $\mathrm{ST}+\mathrm{Tmax}+\mathrm{SR}$ & 3 & 352.575 & 0.827 & 0.974 & 0.746 & 68.4 & & & 10.7 & 20.9 & & & \\
\hline CWD+PRCP & 2 & 353.417 & 0.820 & 0.941 & 0.717 & & & & & & 55.3 & 44.7 & \\
\hline $\mathrm{TPX}+\mathrm{ALB}+\mathrm{PD} 3$ & 3 & 353.948 & 0.821 & 0.978 & 0.735 & & 50.9 & 25.5 & & & & & 23.7 \\
\hline Tmax+ALB+SR & 3 & 357.057 & 0.822 & 0.993 & 0.723 & & 50.9 & & 23.0 & 26.1 & & & \\
\hline $\mathrm{CWD}+\mathrm{SR}$ & 2 & 358.673 & 0.827 & 0.895 & 0.737 & & & & 47.3 & & 52.7 & & \\
\hline $\mathrm{Tmax}+\mathrm{PRCP}+\mathrm{SR}$ & 3 & 373.778 & 0.824 & 0.988 & 0.715 & & & & 47.6 & 19.5 & & 32.8 & \\
\hline $\mathrm{ALB}+\mathrm{PD} 3+\mathrm{SR}$ & 3 & 374.048 & 0.815 & 0.971 & 0.708 & & 55.2 & & 19.9 & & & & 24.9 \\
\hline Tmax+TPX+PRCP & 3 & 376.817 & 0.827 & 0.951 & 0.730 & & & 51.8 & & 17.5 & & 30.7 & \\
\hline Tmax+TPX+PD3+SR & 4 & 378.634 & 0.819 & 0.980 & 0.710 & & & 41.1 & 18.1 & 19.4 & & & 21.4 \\
\hline $\mathrm{ST}+\mathrm{Tmax}+\mathrm{TPX}$ & 3 & 378.772 & 0.819 & 0.984 & 0.696 & 65.7 & & 16.0 & & 18.3 & & & \\
\hline $\mathrm{TPX}+\mathrm{PRCP}+\mathrm{SR}$ & 3 & 382.344 & 0.819 & 0.988 & 0.701 & & & 39.5 & 21.5 & & & 39.0 & \\
\hline $\mathrm{ST}$ & 1 & 388.301 & 0.806 & 0.846 & 0.692 & 100.0 & & & & & & & \\
\hline Tmax+TPX+ALB & 3 & 389.155 & 0.819 & 0.982 & 0.722 & & 46.6 & 28.0 & & 25.5 & & & \\
\hline $\mathrm{ST}+\mathrm{PD} 3+\mathrm{SR}$ & 3 & 395.182 & 0.808 & 0.960 & 0.678 & 71.1 & & & 16.4 & & & & 12.5 \\
\hline $\mathrm{ST}+\mathrm{TPX}+\mathrm{PD} 3$ & 3 & 409.101 & 0.804 & 0.970 & 0.665 & 67.8 & & 20.2 & & & & & 11.9 \\
\hline $\mathrm{PRCP}+\mathrm{SR}$ & 2 & 412.172 & 0.812 & 0.968 & 0.663 & & & & 55.2 & & & 44.8 & \\
\hline CWD+PD3 & 2 & 414.148 & 0.813 & 0.903 & 0.690 & & & & & & 89.1 & & 10.9 \\
\hline Tmax+PRCP & 2 & 418.926 & 0.808 & 0.936 & 0.649 & & & & & 49.9 & & 50.1 & \\
\hline TPX+PRCP & 2 & 428.142 & 0.813 & 0.936 & 0.669 & & & 55.6 & & & & 44.4 & \\
\hline Tmax+PD3+SR & 3 & 428.453 & 0.816 & 0.940 & 0.673 & & & & 49.7 & 23.4 & & & 26.9 \\
\hline Tmax $+\mathrm{TPX}+\mathrm{SR}$ & 3 & 441.567 & 0.806 & 0.958 & 0.644 & & & 42.5 & 17.6 & 39.9 & & & \\
\hline $\mathrm{TPX}+\mathrm{PD} 3+\mathrm{SR}$ & 3 & 442.947 & 0.799 & 0.953 & 0.629 & & & 48.4 & 20.9 & & & & 30.7 \\
\hline ALB & 1 & 443.962 & 0.805 & 0.964 & 0.651 & & 100.0 & & & & & & \\
\hline CWD & 1 & 448.926 & 0.795 & 0.794 & 0.615 & & & & & & 100.0 & & \\
\hline Tmax+TPX+PD3 & 3 & 450.012 & 0.799 & 0.970 & 0.620 & & & 54.2 & & 20.5 & & & 25.3 \\
\hline $\mathrm{ST}+\mathrm{TPX}$ & 2 & 456.197 & 0.795 & 0.986 & 0.618 & 79.8 & & 20.2 & & & & & \\
\hline $\mathrm{ST}+\mathrm{SR}$ & 2 & 461.007 & 0.787 & 0.956 & 0.590 & 82.1 & & & 17.9 & & & & \\
\hline Tmax+TPX & 2 & 462.108 & 0.799 & 0.978 & 0.613 & & & 57.9 & & 42.1 & & & \\
\hline Tmax+SR & 2 & 475.003 & 0.796 & 0.992 & 0.591 & & & & 54.1 & 45.9 & & & \\
\hline $\mathrm{TPX}+\mathrm{ALB}+\mathrm{SR}$ & 3 & 493.642 & 0.794 & 0.970 & 0.596 & & 64.1 & 24.6 & 11.3 & & & & \\
\hline $\mathrm{TPX}+\mathrm{PD} 3$ & 2 & 495.933 & 0.782 & 0.935 & 0.593 & & & 66.8 & & & & & 33.2 \\
\hline TPX+ALB & 2 & 496.902 & 0.790 & 0.991 & 0.584 & & 66.8 & 33.2 & & & & & \\
\hline Tmax+PD3 & 2 & 499.091 & 0.793 & 0.978 & 0.606 & & & & & 72.1 & & & 27.9 \\
\hline $\mathrm{ALB}+\mathrm{SR}$ & 2 & 525.527 & 0.787 & 0.959 & 0.557 & & 73.6 & & 26.4 & & & & \\
\hline$T \max$ & 1 & 525.552 & 0.782 & 0.951 & 0.556 & & & & & 100.0 & & & \\
\hline $\mathrm{PD} 3+\mathrm{SR}$ & 2 & 541.217 & 0.787 & 0.938 & 0.569 & & & & 66.2 & & & & 33.8 \\
\hline PRCP & 1 & 543.177 & 0.771 & 0.864 & 0.529 & & & & & & & 100.0 & \\
\hline $\mathrm{TPX}+\mathrm{SR}$ & 2 & 651.202 & 0.750 & 0.967 & 0.403 & & & 68.3 & 31.7 & & & & \\
\hline TPX & 1 & 711.650 & 0.716 & 0.862 & 0.367 & & & 100.0 & & & & & \\
\hline SR & 1 & 727.974 & 0.724 & 0.853 & 0.328 & & & & 100.0 & & & & \\
\hline PD3 & 1 & 889.101 & 0.622 & 0.764 & 0.151 & & & & & & & & 100.0 \\
\hline
\end{tabular}



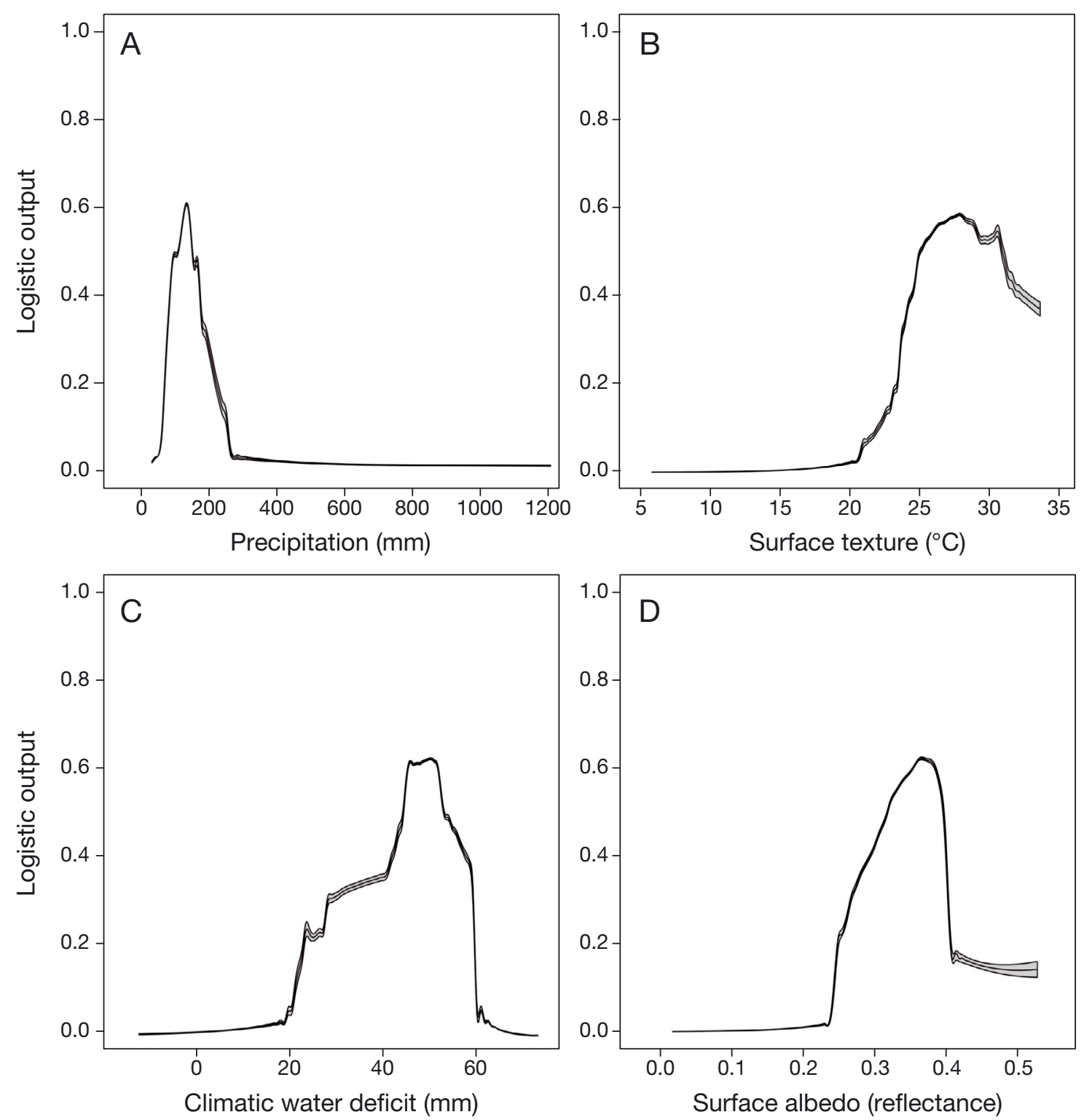

Fig. 1. Marginal response curves for the Mohave ground squirrel Xerospermophilus mohavensis habitat model illustrating how the model output varies over the entire range of each covariate while all other covariates are held at their mean values. (A) Average cumulative winter precipitation, (B) surface texture, (C) average winter climatic water deficit, (D) summer surface albedo. Upper and lower $95 \%$ confidence intervals over the 100 replicates are shown in light grey

to areas with high proportions of large boulders and surface bedrock, and also in areas where differences were above $30^{\circ} \mathrm{C}$, which are indicative of playas (primarily clay components) and extremely fine sandy surfaces. Surface texture was the limiting layer for $20349 \mathrm{~km}^{2}$ of the study area equating to approximately $45 \%$ of the area that was classified as unsuitable habitat (Fig. 2). These areas included the majority of the mountains, foothills and rocky terrain in our study area, along with extensive areas of fine sand and silty, dry lakebeds.
In contrast to surface texture, surface albedo provided a measure of the substrate material type, and differentiated substrates based on the proportions of incident solar energy that are absorbed by different soil types. Surface albedo had the second highest percent contribution at $25.4 \%$, and showed a range ( 0.25 to 0.40 ) of values contributing to high habitat suitability (Fig. 1) from the entire study area, which ranged from 0.02 to 0.52 (Fig. 2). We found that only $27 \%\left(12250 \mathrm{~km}^{2}\right)$ of unsuitable habitat was limited by surface albedo (Fig. 2). We found that MGS 


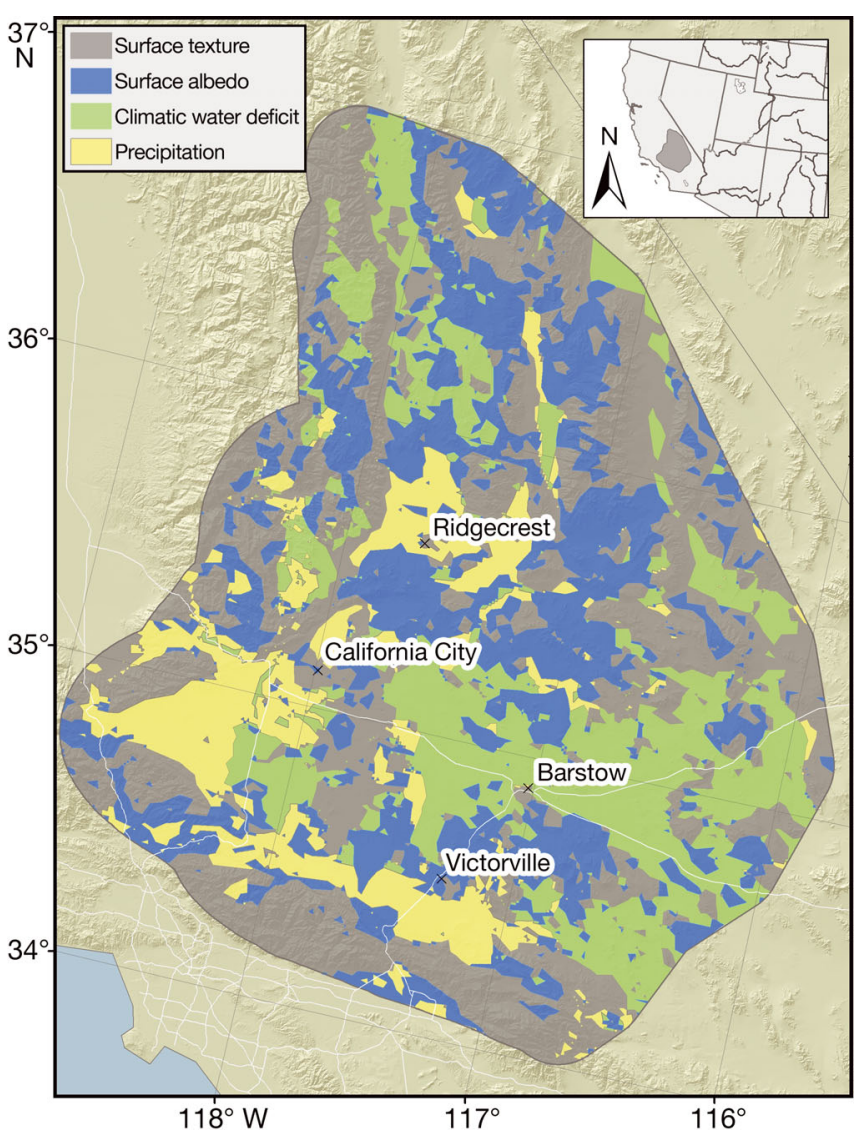

Fig. 2. Limiting covariates (surface texture, brown; albedo, blue; climatic water deficit, green; precipitation, yellow) for the study area in the selected habitat model for Mohave ground squirrel (MGS; Xerospermophilus mohavensis). The limiting covariate for a given grid cell was identified as the covariate providing the greatest increase in habitat suitability for that grid cell if the covariate value was adjusted to its mean of the entire study area. Roads (white lines) and selected cities are shown for reference

tended to occur in areas with higher albedos, as long as the substrates were not rocky or extremely sandy in texture. For example, areas with high albedo rocks in portions of the Red Rock Canyon State Park (southwest of Ridgecrest, CA) may appear suitable in terms of color and material, but due to their surface texture (extensive surface rock), they remained unsuitable. The same was true for many of the sand dunes present throughout our study area, where surface albedo suggested acceptable conditions, yet surface texture was too fine for MGS.

The percent contribution for climatic water deficit was $16.3 \%$. Climatic water deficit influenced habitat suitability over a relatively broad range of values found in the study area, with increased suitability occurring between 20 and $55 \mathrm{~mm}(60 \%$ of the study

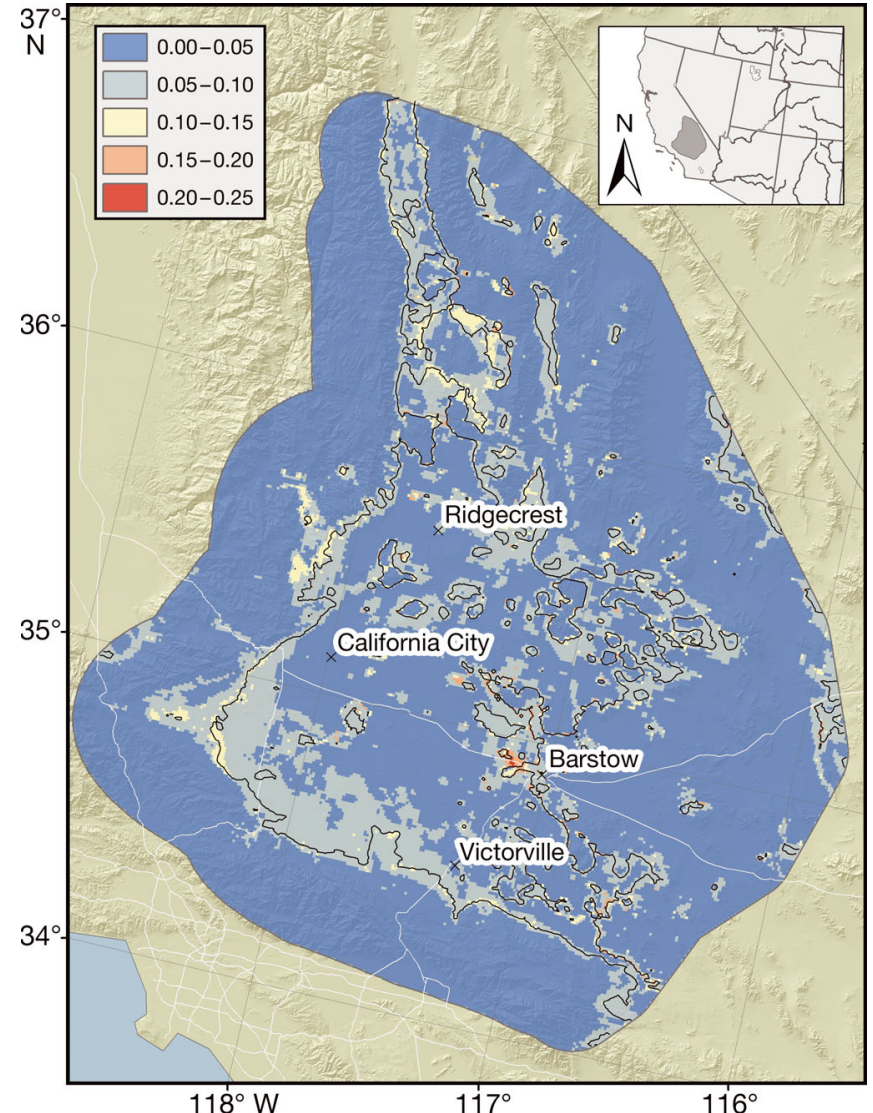

Fig. 3. Model standard deviation map. Warmer colors represent areas with high standard deviations among the 100 bootstrap replicates. The model was based on 440 input localities. Modeling was conducted at a scale of $1 \mathrm{~km}$ (raster cell size $=1000 \mathrm{~m}$ ). The threshold between suitable and unsuitable habitat is shown as a black contour. Roads (white lines) and selected cities are shown for reference

area), and a marked decrease in habitat suitability above $60 \mathrm{~mm}$ and below $20 \mathrm{~mm}$ of winter climatic water deficit (Fig. 1). As a limiting layer, climatic winter deficit covered $20 \%$ of the unsuitable areas $\left(8760 \mathrm{~km}^{2}\right.$; Fig. 2), where average deficit was generally higher than $60 \mathrm{~mm}$.

Precipitation had the lowest contribution of the 4 environmental covariates at $11.6 \%$. MGS habitat exhibited a relatively narrow band of suitable values for precipitation $(90-200 \mathrm{~mm}$ ) when compared with the range of precipitation found in the study area $(0$ to nearly $1200 \mathrm{~mm}$ ). This narrow range of suitable precipitation values represented nearly $50 \%$ of the study area (Fig. 1). As a limiting layer, precipitation represented only $9 \%$ of the unsuitable habitat (3930 $\mathrm{km}^{2}$; Fig. 2), and in those areas, precipitation was higher than the average of suitable areas. Standard deviations of habitat suitability values across 
the 100 replicates ranged from nearly 0 to 0.206 , with the highest standard deviations occurring in areas with moderate habitat suitability scores near the threshold used to distinguish suitable and unsuitable habitat (Fig. 3). Areas with the highest standard deviations occurred directly to the west of Barstow, CA (Fig. 3), and tended to have very fine surface texture and high surface albedo.

\section{Impact scenarios}

When we simulated a historical context of original habitat conditions prior to European settlement, the model predicted $19023 \mathrm{~km}^{2}$ of suitable habitat. We compared the amount of suitable habitat under these conditions with our 3 urban development scenarios of impact to evaluate potential habitat losses due to urban development. We found that potential habitat was reduced to 15927,16525 and $17139 \mathrm{~km}^{2}$ for the high, medium and low scenarios, respectively (Table 2). These scenarios estimate that somewhere between $1884 \mathrm{~km}^{2}(9.9 \%)$ and $3096 \mathrm{~km}^{2}$ (16.3\%) of predicted suitable habitat have already been lost to the development of urban areas, roads and cleared vegetation during recent human settlements in the region.

The addition of proposed USRED indicates the potential to further reduce suitable habitat to 14369 , 16142 or $17058 \mathrm{~km}^{2}$ for the high (Fig. 4A), medium and low scenarios of USRED impact, respectively. This represents an additional loss of 1558 (9.8\%), 383 $(2.3 \%)$ and $81 \mathrm{~km}^{2}(0.5 \%)$ of suitable habitat over our 3 urban development scenarios of impact. When
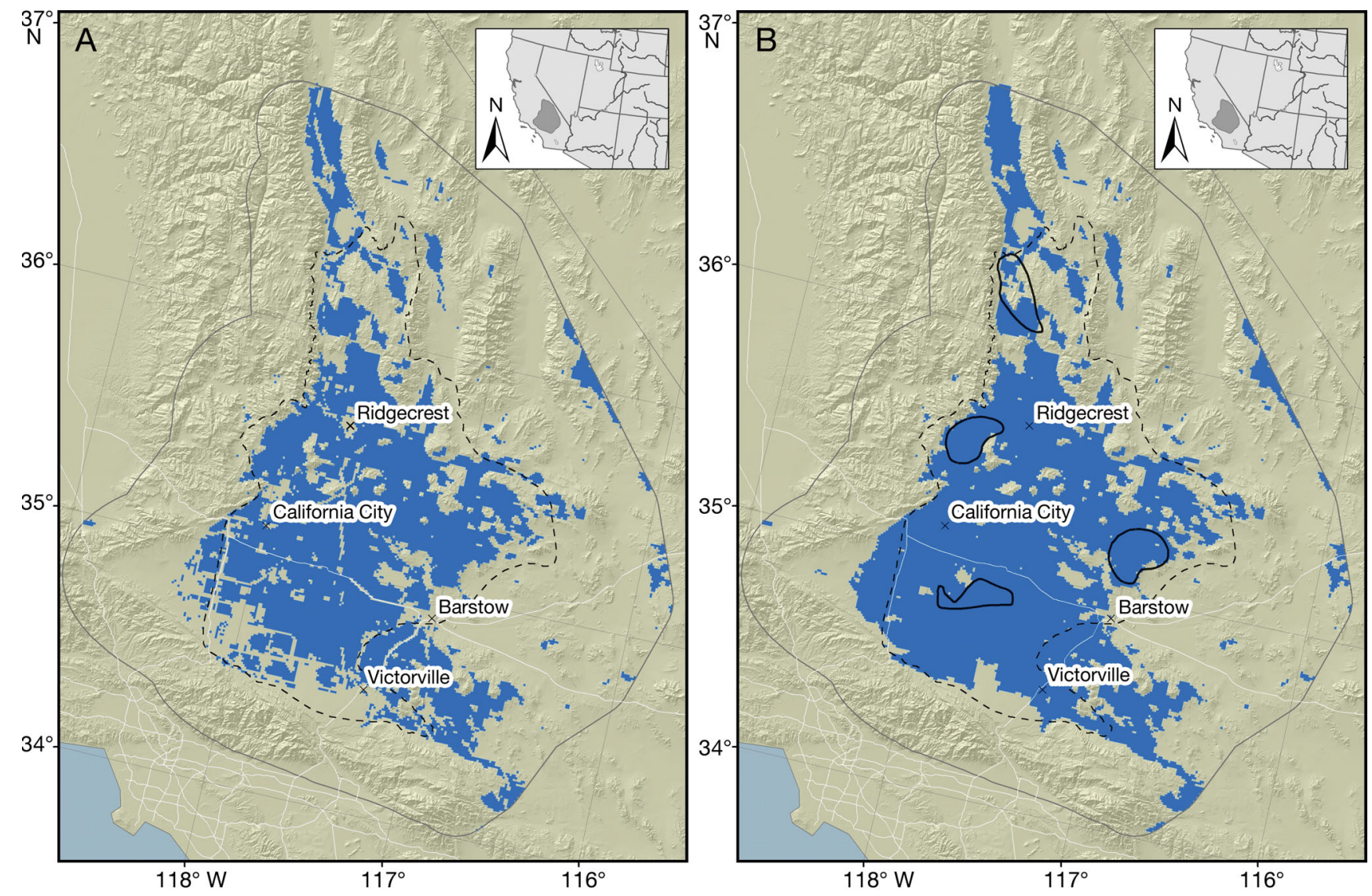

Fig 4. (A) Suitable habitat (blue) for Mohave ground squirrel (MGS; Xerospermophilus mohavensis) under the high human development impact scenario (including anthropogenic and renewable energy influences). Of the 3 human development impact scenarios, the High scenario represents the greatest level of impact to MGS habitat due to impermeable surfaces, major roads, and cleared vegetation. We subtracted the product of the corresponding habitat suitability score and a scale factor score (urban: 1.0 ; roads: from 0.4 ; vegetation: 1.0 ) from the habitat suitability score. Habitat suitability scores for areas of proposed utility-scale renewable energy development projects were also reduced using scale factors of 0.5 for transmission corridors and wind facilities, and 1.0 for solar facilities in the High scenario. (B) Historic habitat suitability without consideration of urban, roads or cleared vegetation. Core areas (Leitner 2008) are outlined in solid black. The MGS range map is outlined in hashed black on both maps, while major roads are shown for reference in white 
added to losses due to current levels of development, this represents an overall loss of 24.5, 15.1 and $10.3 \%$ of suitable habitat from potential pre-European development levels.

We found that the average habitat suitability score was higher by $0.077,0.081$ and 0.093 in areas with proposed USRED than the rest of the study area for each of the 3 scenarios, respectively. This suggests that areas proposed for USRED are located in areas of high suitability habitat. When we compared the amount of suitable habitat in the different types of proposed USRED (wind versus solar), we found that the difference was substantial, with only $2 \mathrm{~km}^{2}$ of suitable habitat in proposed solar development in each of the 3 urban development scenarios of impact, and 503, 508 and $522 \mathrm{~km}^{2}$ of suitable habitat in areas of proposed wind development for the 3 urban development scenarios of impact.

\section{DISCUSSION}

\section{Historical habitat change}

Overlaying predicted habitat for the MGS with our human development scenarios of impact indicates that somewhere between 10 and $16 \%$ of historic suitable habitat has been lost to urbanization to date. We considered the potential impacts of proposed renewable energy development using 3 scenarios of potential impact, which predicted additional losses of 1 to $10 \%$ of historic suitable habitat for MGS, or a potential loss of up to $24 \%$ of suitable habitat within recent history. However, this is likely an underestimate of the potentially impacted area, because our model of habitat is estimated across all land ownership categories, yet we were only able to obtain data to estimate the footprint of USRED on public lands. On state and private lands, $260 \mathrm{~km}^{2}$ in the region have proposals for USRED, and an additional $3500 \mathrm{~km}^{2}$ may potentially be available for USRED (Fish and Wildlife Service 2011). Our model of habitat indicates that there is potential for renewable energy development to impact nearly as much habitat as has previously been disturbed by human expansion into this region, equating to a loss of up to a quarter of suitable habitat from pre-European settlement levels within the last century.

Encroachment of urban areas on MGS habitat introduces several modes of habitat disturbance, including off-highway vehicles, roadways, airports and high-voltage transmission lines (Leitner 2008) that affect habitat and populations of flora and fauna in a variety of ways. Additional USRED in the region will increase the need for more transmission lines and associated roads, and combined with the energy facilities themselves, loss of habitat and other impacts on species may occur from site preparation and construction of buildings and access roads (Kuvlesky et al. 2007). Other changes to habitat may be caused by soil mixing or soil compaction, or the release of chemicals such as dust suppressants, dielectric fluids and herbicides throughout the operational life of the facility (BLM 2012). Separately, the alteration of surface water flow and increased erosion may cause changes in habitat productivity and the distribution of resources (Schwinning et al. 2011).

Transmission corridors tend to alter the vegetation community and structure of adjacent land, and therefore affect habitat through these vegetation alterations (Anderson et al. 1977, Johnson et al. 1979, Loft \& Menke 1984, Clarke et al. 2006, King et al. 2009). These corridors may be permeable or even facilitate movement in some species, but may represent barriers to movement and dispersal for others (Schreiber \& Graves 1977, Carthew et al. 2009). The influence on habitat and populations may also be larger than the physical footprint of USRED because human activities and the physical structures tend to provide resource subsidies such as food, cover and water to native and invasive predators (Lovich \& Bainbridge 1999). Transmission corridors and roads may also act as conduits for exotic and invasive species (Stiles \& Jones 1998, Gelbard \& Belnap 2003). For example, powerlines, roads and other linear right-of-ways provide nesting and perching sites for predatory birds, including the common raven Corvus corax (Kristan \& Boarman 2003, Coates et al. 2008, Peery \& Henry 2010). Ravens and coyotes Canis latrans, subsidized by human activities, can have detrimental effects on native wildlife in proximity to urban locations (Lovich \& Bainbridge 1999, Boarman 2003, Esque et al. 2010). While increased predation on native wildlife has caused population losses in other species, and is likely to similarly impact MGS populations, research is needed to quantify the landscape-wide effects of urbanization on MGS populations.

\section{Utility-scale renewable energy development}

The long-term effects of renewable energy development on MGS populations are also not well understood. Potential effects are complicated by differences between wind, solar, geothermal and other sources of USRED. The diffuse distribution of wind 
turbines with relatively undisturbed habitat among turbine bases has been suggested as not harmful and may even provide cover for desert tortoises (Lovich et al. 2011). However, the impacts of wind energy development on other desert wildlife, including the MGS, are not well understood (Lovich \& Ennen 2011). In other studies, wind energy facilities have been shown to elicit increased alert vocalizations and anti-predator vigilance behavior in the California ground squirrel due to the addition of wind turbine prop noise to their environment (Rabin et al. 2006). A review of acoustical interference in wildlife has shown negative population effects across a wide range of taxa, including mammals, birds, amphibians, reptiles and even some invertebrates (see Chan \& Blumstein 2011 for a review), with the majority of effects manifesting as interference to communication between individuals, increased energy expenditures on predator avoidance, and population decline. The effects of wind and solar energy development on MGS behavior and population dynamics are not well understood and are important areas for research.

\section{Application of habitat modeling}

To illustrate the utility of our habitat model for regional planning purposes, we compared it with a previously published range map (Zeiner et al. 19881990) and core habitat areas (Leitner 2008). The previously published range for MGS represents a hypothesis for the historical range and extent of MGS in the western Mojave Desert, and has served as a guide for implementing conservation strategies in this region (BLM 2005) and the foundation for the 2011 Fish and Wildlife Service decision to deny MGS listing under the Endangered Species Act. Our model of MGS habitat illustrates that many areas within the extent of the previously published MGS range map are not suitable as habitat for MGS (Fig. 4A), and that much of the northern and eastern portions of the previously published range map contain unsuitable habitat. When applied to conservation, these differences in geographic area represent substantial differences between estimates of the amount of habitat that will be affected by USRED. In their 2011 decision, the Fish and Wildlife Service suggest that up to $6 \%$ of the MGS range may be affected by USRED on public and private lands, while in contrast, our high impact scenario suggests that up to $10 \%$ of current habitat will be negatively affected by USRED on public federal land alone. With an additional $3500 \mathrm{~km}^{2}$ of state and private land in our study area, the amount of MGS habitat affected by USRED may be substantially higher.

We also show areas with suitable habitat outside the MGS range map (Fig. 4B), though these areas have never been surveyed for MGS, and may represent uninhabited areas that have not been colonized. Such areas include suitable habitat farther north in the Owen's Valley than was previously thought, as well as farther south and east of Apple Valley than was previously published. Unlike the previously published range map, the published core areas represent areas where populations of MGS have been detected for multiple years in large (>30) numbers at multiple trapping sites (>6; Leitner 2008). These areas are thought to represent population centers, and have been suggested as key areas for MGS conservation (Leitner 2008). In general, these core areas overlapped some of the highest habitat suitability, although the northernmost core area encompassed lower habitat suitability than the others (Fig. 4B). This core area was designated due to the high numbers of MGS trapped at its most northern and southern end, though few MGS have been observed in its central region.

One proposed USRED in particular was noted in an area of high suitability habitat located northwest of Red Rock Canyon State Park, and approximately $30 \mathrm{~km}$ south and west of Ridgecrest, CA. In addition to high suitability habitat, this area has some of the highest densities of trapping records, may serve as an important corridor for dispersal among populations (P. J. Weisberg et al. unpubl. data), and is a region of high genetic variation that harbors one of 3 distinct genetic groups within the species (Bell \& Matocq 2011). Siting future USRED away from areas with high suitability habitat may promote MGS population persistence.

\section{Model bias}

Identifying areas where habitat models provide less certainty about their predictions of habitat suitability is crucial for land-use planning purposes because of the consequences to conservation if unsuitable rather than suitable habitat is conserved. For example, if the reliance on erroneous habitat suitability models leads to the siting of land-use activities that are incompatible with conservation on remaining MGS habitat, regional planning efforts will be unable to meet conservation goals. It is crucial, therefore, to acknowledge and understand model error and model bias when interpreting and incorporating 
model predictions into planning efforts. Others have also suggested that error maps be included with all habitat models, regardless of the methods used to create them (Rocchini et al. 2011). Doing so will promote awareness that no model is absent of error or bias.

We provide estimates of model uncertainty throughout our study area to identify areas where our model yielded greater uncertainty about predictions of habitat suitability (Fig. 3). These areas were identified for their high variation in model prediction among the 100 training iterations (each with a random selection of $80 \%$ of observations). While we found the greatest uncertainty in a valley directly to the west of Barstow, CA (Fig. 3), we also found high uncertainty in areas with very fine surface texture and high surface albedo. These areas tended to have moderate habitat suitability scores near our threshold for delineating suitable and unsuitable habitat. This suggests that our model predicts high suitability scores and low suitability scores with greater precision than it does moderate suitability scores, and that the transition between unsuitable and suitable habitat is less certain than either of the extremes.

Among the factors contributing to this error were the multiple sources of observation data, each with its own pattern of geographic bias due to non-random sampling. This bias has been shown to influence the perceived relationship between a species and its environment (Hortal et al. 2008, Soberón \& Nakamura 2009), thereby compromising the ability to quantify the ecological niche for a species. However, we were less concerned with the ability to quantify the ecological niche of MGS than we were with developing a predictive, yet biologically plausible, model for the current geographic distribution of MGS habitat. Another source of error was the temporal span of our input observations, which dated back to 1975 to increase sample size. However, because of the rapid population growth in the past several decades, locations for some of the observations are now in areas with urban development or agriculture. We reduced potential bias from these land-use changes by limiting our environmental covariates to those that have remained relatively unchanged by land use over the past $30 \mathrm{yr}$.

We identified 2 easily discernible types of areas where additional sampling could improve future habitat models and benefit conservation planning for MGS. The first included areas with moderate to high suitability scores with no evidence of MGS presence, and the second included areas with high model error, as shown in Fig. 3. Areas that met the first condition likely occurred because of one of 3 reasons: (1) our model predicted high suitability habitat and sampling did not occur, (2) our model predicted high suitability habitat and sampling did occur, but no MGS were detected even though they were present, and (3) our model predicted high suitability habitat and sampling did occur, but MGS were not detected and were not present. The first provided the single largest amount of sample selection bias, due to a lack of random (or stratified random) sampling over large areas of potential habitat, which confounds the distribution of sampling effort with the true species distribution (Hortal et al. 2008, Soberón \& Nakamura, 2009). We were unable to distinguish these areas from those where sampling occurred, but no MGS were detected (reasons 2 and 3) because absence data were not available. Absence data require the use of repeated presence-absence surveys to estimate the probability of detection (MacKenzie et al. 2002), which is needed to estimate the confidence or reliability of absence data (MacKenzie et al. 2006, Kéry et al. 2010). Camera trapping surveys for MGS were designed to obtain presence-absence data and have recently been implemented, though few data are available for modeling. Areas meeting the second condition for additional sampling included areas with high model error, which are shown in Fig. 3.

We recommend continued and increased sampling efforts in areas that meet these 2 conditions, especially in areas where sampling has not yet occurred and which are predicted to have moderate to high suitability habitat. In particular, the China Lake Naval Air Weapons Center encompasses areas of high suitability habitat $(>0.7)$, yet has had little sampling. This military installation also includes some of the most northerly predictions of suitable habitat, and will be important for interpreting conservation issues such as conservation genetics, habitat connectivity and MGS responses to climate change.

\section{Tools for conservation}

Habitat suitability modeling has provided a new status-of-knowledge for the MGS that managers can use to make informed decisions about resource management in or near MGS habitats. Using this model it is possible to provide quantitative estimations of historical habitat availability, current suitable habitat availability, species use and connectivity across landscapes, and to predict trends in the availability of habitat based on resource management plans. Sound resource management decisions depend on reliable 
information on habitat, populations and threats. As our most complete current understanding of suitable habitat for this species, this model provides a valuable planning resource, but equally important, the model helps identify critical areas in need of research to strengthen future modeling efforts for this species.

Acknowledgements. We thank R. Scofield (California BLM) and B. Hogan (US Fish and Wildlife Service) for encouraging us to embark on this research project and for technical support and communications throughout the process. M. Milliron and D. Stoms (California Energy Commission), and S. Jones (US Geological Survey) provided product management and financial resources. Partial funding was provided by the California Energy Commission and the US Geological Survey Program in Ecological Studies, Recoverability and Vulnerability of Desert Ecosystems Project. G. Miller (California Desert District BLM) shared GIS data sets that were integral to the success of the work. T. Lupo (California Natural Diversity Data Base, California Department of Game and Fish) collaborated on the use of MGS databases, and F. Duke (Mojave Desert Ecosystem Program) also provided data. D. Delaney (CERL) analyzed and shared recently acquired field and previously unpublished data on squirrel presence. S. Glushkoff (California Department of Fish and Game) shared insights on management implications of this work. A. Rager (US Geological Survey) digitized many of the field survey reports used to access MGS observations. We thank B. Halstead (US Geological Survey) and 2 anonymous reviewers for improving the manuscript. Any use of trade, product or firm names in this publication is for descriptive purposes only and does not imply endorsement by the US government.

\section{LITERATURE CITED}

Anderson SH, Mann K, Shugart JHH (1977) The effect of transmission-line corridors on bird populations. Am Midl Nat 97:216-221

Bartholomew GA, Hudson JW (1961) Desert ground squirrels. Sci Am 205:107-117

Beatley JC (1976) Rainfall and fluctuating plant populations in relation to distributions and numbers of desert rodents in southern Nevada. Oecologia 24:21-42

Bell KC, Matocq MD (2011) Regional genetic subdivision in the Mohave ground squirrel: evidence of historic isolation and ongoing connectivity in a Mojave Desert endemic. Anim Conserv 14:371-381

Best TL (1995) Spermophilus mohavensis. Mammalian Species No 509. Mammal Species 509:1-7

Blainey JB, Webb RH, Magirl CS (2007) Modeling the spatial and temporal variation of monthly and seasonal precipitation on the Nevada test site and vicinity, 1960-2006. US Geological Survey Open-file Report 2007-1269

BLM (Bureau of Land Management) (1980) California desert conservation area plan. BLM, US Dept of the Interior, Riverside, CA. Available at www.blm.gov/pgdata/etc/ medialib//blm/ca/pdf/pdfs/cdd_pdfs.Par.aa6ec747.File. pdf/CA_Desert_.pdf (accessed 18 July 2012)

BLM (Bureau of Land Management) (2005) Final environ- mental impact report and statement for the West Mojave plan: a habitat conservation plan and California desert conservation area plan amendment. BLM, US Dept of the Interior, Moreno Valley, CA. Available at www.blm.gov/ ca/pdfs/cdd_pdfs/wemo_pdfs/plan/wemo/Vol-1Chapter1_Bookmarks.pdf (accessed 18 July 2012)

BLM (Bureau of Land Management) (2009) Approved resource management plan amendments/record of decision (ROD) for designation of energy corridors on Bureau of Land Management-administered lands in the 11 western states. BLM, US Dept of the Interior, Washington, DC. Available at http://corridoreis.anl.gov/ documents/docs/Energy_Corridors_final_signed_ROD_1 _14_2009.pdf (accessed 18 July 2012)

BLM (Bureau of Land Management) (2012) Programmatic environmental impact statement for solar energy development in six southwestern states. BLM, US Dept of the Interior, Washington, DC. Available at: http://solareis. anl.gov/documents/fpeis/Solar_FPEIS_ExecutiveSummary .pdf (accessed 16 July 2012)

Boarman WI (2003) Managing a subsidized predator population: reducing common raven predation on desert tortoises. Environ Manag 32:205-217

Boyce M, Vernier P, Nielsen S, Schmiegelow F (2002) Evaluating resource selection functions. Ecol Model 157: 281-300

Burnham KP, Anderson DR (2002) Model selection and multimodel inference. Springer Verlag, Berlin

Burt WH (1936) Notes on the habits of the Mohave ground squirrel. J Mammal 17:221-224

California Department of Fish and Game (2011) State and federally listed endangered and threatened animals of California. California Environmental Quality Act. Biogeographic Data Branch, Sacramento, CA, available at www.dfg.ca.gov/habcon/ceqa/ (accessed 27 July 2012)

- Carthew SM, Horner B, Jones KMW (2009) Do utility corridors affect movements of small terrestrial fauna? Wildl Res 36:488-495

Chan AAY, Blumstein DT (2011) Attention, noise, and implications for wildlife conservation and management. Appl Anim Behav Sci 131:1-7

Clarke DJ, Pearce KA, White JG (2006) Powerline corridors: degraded ecosystems or wildlife havens? Wildl Res 33: 615-626

> Coates PS, Connelly JW, Delehanty DJ (2008) Predators of greater sage-grouse nests identified by video monitoring. J Field Ornithol 79:421-428

> Dickinson RE (1995) Land processes in climate models. Remote Sens Environ 51:27-38

Elith J, Leathwick JR (2009a) Conservation prioritisation using species distribution modeling. In: Moilanen A, Wilson KA, Possingham HP (eds) Spatial conservation prioritization: quantitative methods and computational tools. Oxford University Press, Oxford, p 70-93

> Elith J, Leathwick JR (2009b) Species distribution models: ecological explanation and prediction across space and time. Annu Rev Ecol Evol Syst 40:677-697

> Elith J, Kearney M, Phillips S (2010) The art of modelling range-shifting species. Methods Ecol Evol 1:330-342

- Elith J, Phillips SJ, Hastie T, Dudik M, Chee YE, Yates CJ (2011) A statistical explanation of MaxEnt for ecologists. Divers Distrib 17:43-57

> Esque TC, Nussear KE, Drake KK, Walde AD and others (2010) Effects of subsidized predators, resource variability, and human population density on desert tortoise pop- 
ulations in the Mojave Desert, USA. Endang Species Res 12:167-177

Fahrig L, Rytwinski T (2009) Effects of roads on animal abundance: an empirical review and synthesis. Ecol Soc 14:21

Fielding A, Bell J (1997) A review of methods for the assessment of prediction errors in conservation presence/ absence models. Environ Conserv 24:38-49

Fish and Wildlife Service (1988) Endangered and threatened wildlife and plants; determination of endangered status for the Stephens' kangaroo rat. 50 CFR Part 17. FR Doc 88-22400. Federal Registry, Washington, DC

Fish and Wildlife Service (1990) Endangered and threatened wildlife and plants; determination of threatened status for the Mojave population of the desert tortoise. 50 CFR Part 17. FR Doc. 90-7375. Federal Registry, Washington, DC

Fish and Wildlife Service (1998) Endangered and threatened wildlife and plants; endangered status for the peninsular ranges population segment of the desert bighorn sheep in Southern California. 50 CFR Part 17. FR Doc 98-6998. Federal Registry, Washington, DC

Fish and Wildlife Service (2011) Endangered and threatened wildlife and plants; 12 -month finding on a petition to list the Mohave ground squirrel as endangered or threatened. 50 CFR Part 17. FR Doc 2011-25473. Federal Registry, Washington, DC. Available at www.gpo.gov/ fdsys/pkg/FR-2011-10-06/pdf/2011-25473.pdf (accessed 12 July 2012)

Flint LE, Flint AL (2012) Downscaling future climate scenarios to fine scales for hydrologic and ecological modeling and analysis. Ecol Processes 1:2

Flint A, Flint LE, Hevesi JA, Blainey JM (2004) Fundamental concepts of recharge in the Desert Southwest: a regional modeling perspective. In: Hogan JF, Phillips FM, Scanlon BR (eds) Groundwater recharge in a desert environment: the southwestern United States. Water Science and Application, Vol 9. American Geophysical Union, Washington, DC, p 159-184

Franklin J (2010) Mapping species distributions. Cambridge University Press, Cambridge

Fry J, Xian G, Jin S, Dewitz J, Homer C, Yang L, Barnes C, Herold N, Wickham J (2011) Completion of the 2006 National Land Cover Database for the conterminous United States. PE\&RS 77:858-864

Gelbard JL, Belnap J (2003) Roads as conduits for exotic plant invasions in a semiarid landscape. Conserv Biol 17: $420-432$

Graham CH, Ferrier S, Huettman F, Moritz C, Peterson AT (2004) New developments in museum-based informatics and applications in biodiversity analysis. Trends Ecol Evol 19:497-503

Guisan A, Zimmermann N (2000) Predictive habitat distribution models in ecology. Ecol Model 135:147-186

Gustafson JR (1993) A status review of the Mohave ground squirrel (Spermophilus mohavensis). California Department of Fish and Game, Nongame Bird and Mammal Section, Sacramento, CA

Hall ER 1981. The mammals of North America. Wiley, New York, NY

> Harris JH, Leitner P (2004) Home-range size and use of space by adult Mohave ground squirrels, Spermophilus mohavensis. J Mammal 85:517-523

Hereford R, Webb RH, Longpre CI (2004) Precipitation history of the Mojave Desert region, 1893-2001. US Geological Survey Fact Sheet 117-03 2004
Hobson R (1972) Surface roughness in topography: quantitative approach. In: Chorley RJ (ed) Spatial analysis in geomorphology. Harper \& Row, New York, NY, p 221-245

Hortal J, Jiménez-Valverde A, Gómez JF, Lobo JM, Baselga A (2008) Historical bias in biodiversity inventories affects the observed environmental niche of the species. Oikos 117:847-858

Hoyt DF (1972) Mojave ground squirrel survey. California Department Fish Game, Special Wildlife Investigation. Final Report W-54-R-4 II-5. California Dept of Fish and Game, Sacramento, CA

> Huntley B, Berry P, Cramer W, McDonald A (1995) Modelling present and potential future ranges of some European higher plants using climate response surfaces. J Biogeogr 22:967-1001

Johnson WC, Schreiber RK, Burgess RL (1979) Diversity of small mammals in a powerline right-of-way and adjacent forest in East Tennessee. Am Midl Nat 101:231-235

Kahle AB (1987) Surface emittance, temperature, and thermal inertia derived from thermal infrared multispectral scanner (TIMS) data for Death Valley, California. Geophysics 52:858-874

Kéry M, Gardner B, Monnerat C (2010) Predicting species distributions from checklist data using site-occupancy models. J Biogeogr 37:1851-1862

King DI, Chandler RB, Collins JM, Petersen WR, Lautzenheiser TE (2009) Effects of width, edge and habitat on the abundance and nesting success of scrub-shrub birds in powerline corridors. Biol Conserv 142:2672-2680

Kristan WB, Boarman WI (2003) Spatial pattern of risk of common raven predation on desert tortoises. Ecology 84 : 2432-2443

- Kuvlesky WPJ, Brennan LA, Morrison ML, Boydston KK, Ballard BM, Bryant FC (2007) Wind energy development and wildlife conservation: challenges and opportunities. J Wildl Manag 71:2487-2498

Leitner P (2008) Current status of the Mohave ground squirrel. Trans West Section Wildl Soc 44:11-29

Lenihan J, Neilson R (1993) A rule-based vegetation formation model for Canada. J Biogeogr 20:615-628

Leu M, Hanser SE, Knick ST (2008) The human footprint in the west: a large-scale analysis of anthropogenic impacts. Ecol Appl 18:1119-1139

Liu C, Berry P, Dawson T, Pearson R (2005) Selecting thresholds of occurrence in the prediction of species distributions. Ecography 28:385-393

> Loft E, Menke J (1984) Deer use and habitat characteristics of transmission-line corridors in a douglas-fir forest. J Wildl Manag 48:1311-1316

> Lovich JE, Bainbridge D (1999) Anthropogenic degradation of the Southern California desert ecosystem and prospects for natural recovery and restoration. Environ Manag 24:309-326

Lovich JE, Ennen JR (2011) Wildlife conservation and solar energy development in the desert southwest, United States. Bioscience 61:982-992

Lovich JE, Ennen JR, Madrak S, Meyer K and others (2011) Effects of wind energy production on growth, demography, and survivorship of a desert tortoise (Gopherus agassizii) population in Southern California with comparisons to natural populations. Herpetol Conserv Biol 6: 161-174

> MacKenzie DI, Nichols JD, Lachman GB, Droege S (2002) Estimating site occupancy rates when detection probabilities are less than one. Ecology 83:2248-2255 
MacKenzie DI, Nichols JD, Royle JA, Pollock KH, Bailey LL, Hines JE (2006) Occupancy estimation and modeling. Academic Press, Burlington, MA

Moore ID, Grayson RB, Ladson AR (1991) Digital terrain modeling: a review of hydrological, geomorphological, and biological applications. Hydrol Processes 5:3-30

NREL (National Renewable Energy Laboratory) (2011) Dynamic maps, GIS data and analysis tools: solar maps. NREL, US DOI, Washington, DC. Available at www.nrel.gov/gis/solar.html (accessed 6 July 2011)

Oke TR (1987) Boundary layer climates. Routledge, London

> Peery MZ, Henry RW (2010) Recovering marbled murrelets via corvid management: a population viability analysis approach. Biol Conserv 143:2414-2424

Peterson AT, Soberón J, Pearson RG, Anderson RP, Martinez-Meyer E, Nakamura M, Araújo MB (2011) Ecological niches and geographic distributions (MPB-49). Princeton University Press, Princeton, NJ

Phillips SJ, Dudik M (2008) Modeling of species distributions with Maxent: new extensions and a comprehensive evaluation. Ecography 31:161-175

Phillips S, Anderson R, Schapire R (2006) Maximum entropy modeling of species geographic distributions. Ecol Model 190:231-259

Pineda E, Lobo JM (2012) The performance of range maps and species distribution models representing the geographic variation of species richness at different resolutions. Glob Ecol Biogeogr 21:935-944

Pratt D, Ellyett C (1979) The thermal inertia approach to mapping of soil moisture and geology. Remote Sens Environ 8:151-168

> Prentice I, Craimer W, Harrison S, Leemans R, Monserud R, Solomon A (1992) A global biome model based on plant physiology and dominance, soil properties and climate. J Biogeogr 19:117-134

Priestley C, Taylor R (1972) On the assessment of surface heat flux and evaporation using large-scale parameters. Mon Weather Rev 100:81

Rabin LA, Coss RG, Owings DH (2006) The effects of wind turbines on antipredator behavior in California ground squirrels (Spermophilus beecheyi). Biol Conserv 131: 410-420

Rocchini D, Hortal J, Lengyel S, Lobo JM and others (2011) Accounting for uncertainty when mapping species distributions: the need for maps of ignorance. Prog Phys Geogr 35:211-226

Editorial responsibility: Michael Reed,

Medford, Massachusetts, USA
Schreiber RK, Graves JH (1977) Powerline corridors as possible barriers to the movements of small mammals. Am Midl Nat 97:504-508

Schwinning S, Sandquist DR, Miller DM, Bedford DR, Phillips SL, Belnap J (2011) The influence of stream channels on distributions of Larrea tridentata and Ambrosia dumosa in the Mojave Desert, CA, USA: patterns, mechanisms and effects of stream redistribution. Ecohydrology 4:12-25

Soberón J, Nakamura M (2009) Niches and distributional areas: concepts, methods, and assumptions. Proc Natl Acad Sci USA 106(Suppl 2):19644-19650

Stephenson N (1998) Actual evapotranspiration and deficit: biologically meaningful correlates of vegetation distribution across spatial scales. J Biogeogr 25:855-870

Stiles JH, Jones RH (1998) Distribution of the red imported fire ant, Solenopsis invicta, in road and powerline habitats. Landscape Ecol 13:335-346

Theobald DM, Miller JR, Hobbs NT (1997) Estimating the cumulative effects of development on wildlife habitat. Landsc Urban Plan 39:25-36

Turner RM (1994) Mohave desertscrub. In: Brown DE (ed) Biotic communities southwestern United States and northwestern Mexico. University of Utah Press, Salt Lake City, UT, p 157-168

Turner FB, Randall DC (1989) Net productivity by shrubs and winter annuals in southern Nevada. J Arid Environ 17:23-36

Wang PX, Li XW, Sun W, Li XM, Zhang SY, Liu AL (2004) Soil thermal inertia estimation by combining afternoon and morning AVHRR data with a modified diurnal land surface temperature change model. Geoscience and Remote Sensing Symposium, 2004. IGARSS '04. Proceedings. 2004 IEEE International 4299-4301

> Warren DL, Seifert SN (2011) Ecological niche modeling in Maxent: the importance of model complexity and the performance of model selection criteria. Ecol Appl 21: 335-342

Webb RH, Fenstermaker L, Heaton J (2009) The Mojave Desert: ecosystem processes and sustainability. University of Nevada Press, Reno, NV

Zeiner DC, Laudenslayer WF, Mayer KE, White M (1988-1990) California's Wildlife. Vol. I-III. California Department of Fish and Game, Sacramento, CA

> Zembal R, Gall C (1980) Observations on Mohave ground squirrel, Spermophilus mohavensis, in Inyo Co., California. J Mammal 61:347-350

Submitted: September 26, 2012; Accepted: December 11, 2012 Proofs received from author(s): February 8, 2013 